\title{
Influence of Intercropping Maize with Cowpea and Fertilization with Clinoptilolite on Forage Yield and Quality
}

\author{
Ivan Horvatić ${ }^{1}$, Zlatko Svečnjak ${ }^{2}$, Dubravko Maćešić ${ }^{2}$, Dario Jareš ${ }^{2}$ and Darko Uher ${ }^{2}$ \\ 1. Božjakovina d.o.o., Božjakovečka 6, Dugo Selo 10370, Republic of Croatia \\ 2. Department of Field Crops, Forage and Grassland, Faculty of Agriculture, University of Zagreb, Zagreb 10000, Republic of \\ Croatia
}

\begin{abstract}
Maize forage is poor in protein content which leads to low quality and nutritive value. Regarding the high feed costs of protein supplementations, legumes can be used in livestock nutrition for their high protein content, and thus, provide cost savings. In this study, maize (Zea mays L.) and cowpea (Vigna unguiculata L.) were intercropped in different sowing densities and fertilization with clinoptilolite and their monocropping equivalents were tested to determine the best intercropping system on forage yield and quality. Maize was cultivated alone (75,000 plants $\left.\cdot \mathrm{ha}^{-1}\right)$ and intercropped with cowpea as follows: 75,000 plants $\cdot \mathrm{ha}^{-1}$ of maize and 37,500 plants $\cdot \mathrm{ha}^{-1}$ of cowpea $\left(\mathrm{MC}_{1}\right), 75,000$ plants $\cdot \mathrm{ha}^{-1}$ of maize and 50,000 plants $\cdot \mathrm{ha}^{-1}$ of cowpea $\left(\mathrm{MC}_{2}\right)$ and 75,000 plants $\cdot \mathrm{ha}^{-1}$ of maize and 75,000 plants $\cdot \mathrm{ha}^{-1}$ of cowpea $\left(\mathrm{MC}_{3}\right)$, in rows alternating with maize. The highest dry matter yield was produced by $\mathrm{MC}_{3}$ $\left(23.8 \mathrm{t} \cdot \mathrm{ha}^{-1}\right)$, and the lowest by SM $\left(20.7 \mathrm{t} \cdot \mathrm{ha}^{-1}\right)$ in fertilization with clinoptilolite. All intercropped systems had higher crude protein contents, $\mathrm{MC}_{1}\left(101 \mathrm{~g} \cdot \mathrm{kg}^{-1} \mathrm{DM}\right), \mathrm{MC}_{2}\left(108 \mathrm{~g} \cdot \mathrm{kg}^{-1} \mathrm{DM}\right)$ and $\mathrm{MC}_{3}\left(117 \mathrm{~g} \cdot \mathrm{kg}^{-1} \mathrm{DM}\right)$, than the monocrop maize $\left(84 \mathrm{~g} \cdot \mathrm{kg}^{-1} \mathrm{DM}\right)$ in fertilization with clinoptilolite. Intercropping of maize with cowpea and fertilization with clinoptilolite reduced neutral detergent fiber, resulting in increased forage digestibility. Therefore, maize intercropping with cowpea and fertilization with clinoptilolite could substantially increase forage quantity and quality, and decrease requirements for protein supplements as compared with maize monocrop.
\end{abstract}

Key words: Intercropping, natural zeolite clinoptilolite, maize, cowpea, yield, quality.

\section{Introduction}

In many regions of Europe, whole-plant maize silage is the basic feed used in feeding cows and fattening cattle. Also, whole-plant maize silage is the basic feed for us in Croatia and plays a key role in supplying large quantities of digestive fibers and energy-rich forage in animal nutrition. Despite its high energy content, the protein content is low $\left(88 \mathrm{~g} \cdot \mathrm{kg}^{-1}\right)$ compared with legumes silage [1] and needs to be supplemented with proteins for better feed quality [2]. As a cultivation system, intercropping involves planting two or more crops species in the same field $[3,4]$. Intercropping maize with legumes for silage is

Corresponding author: Ivan Horvatić, Ph.D. student, main research field: forage crops. a feasible strategy to improving the level of crude protein [5, 6]. Appropriate spatial arrangements, planting proportions, and maturity dates of components in maize-legume intercropping enchance biological diversity and have many advantages over pure maize cropping. Although maize provides high yield in terms of dry matter, it produces low protein content in fodder. Cowpea, an annual legume with a high level of protein can be mixed with maize to improve forage protein content of diets and, thus, the costs of high quality forage production can be lowered. Ref. [7] worked on intercropping of maize with different legumes, and showed that dry matter yield and crude protein yield of forage were increased by all intercropping compositions compared with the maize monocrop. Intercropping of maize and cowpea 
resulted in more digestible dry matter and also crude protein content than maize mono-cropping [8]. Physiological and morphological differences between intercrop constituents influence their ability to use resources; especially cereals with legumes, have several advantages such as higher overall yields, better soil utilization [9], yield stability of the cropping system [10], better use of light, water and nutrients [7], improved soil conservation [11], soil fertility through biological nitrogen fixation, which increases soil conservation through greater soil coverage as compared to sole cropping, and ensures better soil-susceptible crop in monoculture [10] and better control of pests and weeds [12, 13]. Atmospheric nitrogen fixation using legumes plants can reduce nitrogen competition in the reciprocal intercropping system of legumes and cereals enabling the cereals to use more nitrogen in the soil [14]. This can affect the quality of the fodder intercrop components because the protein content is directly related to the content of nitrogen in the forage plants [15]. Nutrients use efficiency can also be achieved through the use of clinoptilolite zeolite because the unique physical and chemical properties of clinoptilolite zeolite coupled with their abundance in sedimentary deposits and in rocks derived from volcanic parent materials have made them useful in many agricultural applications [16]. Clinoptilolite zeolite is widely used in cultivating different crops such as cereals, forage, vegetables, vine and fruit crops due to their exceptionally high ion-exchange capacity [17]. This study was designed to determine the influence of different patterns of maize-cowpea intercropping and fertilization with natural zeolite clinoptilolite on the yield and quality of forage.

\section{Material and Methods}

A field experiment was carried out during the 2017 growing season at experimental fields in Oborovo (45 $40^{\prime} 54^{\prime \prime} \mathrm{N} 16^{\circ} 15^{\prime} 12.5^{\prime \prime}$ E), Croatia. Meteorological data of the experimental site are presented in Table 1.
The experiment was set up as a randomized complete block design with three replicates. Maize hybrid seed (KWS Kolumbaris) was obtained from Seed Company "KWS". Seed of the cowpea cultivar "Dolga vigna" was obtained from Company "Sjemenarna". The treatment comprising the individual plot size was 50 $\mathrm{m} \times 2.8 \mathrm{~m}$. The maize population 75,000 plants $\cdot \mathrm{ha}^{-1}$ $(\mathrm{SM})$ were spaced at $70 \mathrm{~cm} \times 19 \mathrm{~cm}$ and cowpea population 37,500 $\left(\mathrm{MC}_{1}\right), 50,000\left(\mathrm{MC}_{2}\right)$ and 75,000 plants $\cdot \mathrm{ha}^{-1}\left(\mathrm{MC}_{3}\right)$ were spaced at $70 \mathrm{~cm} \times 38.1 \mathrm{~cm}, 70$ $\mathrm{cm} \times 28.6 \mathrm{~cm}$ and $70 \times 19 \mathrm{~cm}$, respectively, in rows alternating with maize. Basic tillage was carried out by ploughing to $30 \mathrm{~cm}$ depth. Presowing preparation was done using a tractor-mounted rototiller. All plots were fertilized with the same amount of fertilizer before sowing, containing $200 \mathrm{~kg}$ of $\mathrm{N} \cdot \mathrm{ha}^{-1}, 100 \mathrm{~kg}$ $\mathrm{P}_{2} \mathrm{O}_{5} \mathrm{ha}^{-1}$ and $200 \mathrm{~kg}$ of $\mathrm{K}_{2} \mathrm{O} \mathrm{ha}^{-1}$ in variant of control and additionally in the vegetation of crops (stage six maize leaves) and introduced supplementation of 300 $\mathrm{kg}$ natural zeolite clinoptilolite $\cdot \mathrm{ha}^{-1}$. Clinoptilolite used in this work originated from Slovakia, and the particles size of zeolite ranged in size from 0.5 to 2.0 $\mathrm{mm}$. Maize and cowpea were sown to a depth of approximately $5 \mathrm{~cm}$ by maize drill in May 6, 2017 . Herbicide Wing P (active substance $212.5 \mathrm{~g} / \mathrm{L}$ dimethenamid-P and $250 \mathrm{~g} / \mathrm{L}$ pendimethalin) was applied pre emergence in intercropping maize with cowpea at a dose of $4 \mathrm{~L} \cdot \mathrm{ha}^{-1}$. The soil of the research area has an acid $\mathrm{pH} 4.2$ reaction $(\mathrm{M}-\mathrm{KCl})$, good humus $(3.2 \%)$, poorly supplied with physiologically active phosphorous (4.6 mg $\mathrm{P}_{2} \mathrm{O}_{5} / 100 \mathrm{~g}$ soil), medium supplied with physiologically active potassium (20.0 mg $\mathrm{K}_{2} \mathrm{O} / 100 \mathrm{~g}$ soil) and richly supplied with total nitrogen amounting to $0.17 \%$. The fresh fodders were manually harvested when the maize reached soft dough stage and cowpea at $\mathrm{R} 8$ stage and then chopped into $20 \mathrm{~mm}$ size pieces with a chaff cutter. The dry matter content was determined by drying in an oven at a temperature of $65{ }^{\circ} \mathrm{C}$ to a constant mass. Crude protein was measured according to Kjeldahl, calcium was analysed by atomic absorption spectrophotometry 
Table 1 Mean monthly air temperature and rainfall during the 2017 growing season.

\begin{tabular}{lllllll}
\hline Meteorological data & Month & & & & \\
\hline & April & May & June & July & August & September \\
\hline Air temperature $\left({ }^{\circ} \mathrm{C}\right)$ & 11.9 & 17.3 & 22.4 & 23.3 & 22.7 & 14.8 \\
Rainfall $(\mathrm{mm})$ & 41.6 & 49.2 & 57.8 & 91.8 & 32.0 & 186.3 \\
\hline
\end{tabular}

and phosphorus was analysed by colorimetry [18] and neutral detergent fibre according to Ref. [19]. The WSC (Water Soluble Carbohydrate) was determined by the anthrone method, using freeze dried samples, where the WSC was extracted with water [20]. Analyses of variance were made for fresh fodder and dry matter yield and forage quality parameters $(p<$ $0.05)$, and the Tukey test was used for comparing means $(p<0.05)$. Data were analyzed using SAS statistical software (SAS Inst., 2002) [21].

\section{Results and Discussion}

Table 2 shows the yield of forage and dry matter of maize intercropped wih cowpea. The diferences in the yield of forage are statistically significant and yield of dry matter is not statistically significant $(p<0.05)$. The yield of forage and dry matter yield ranged from $61.8 \mathrm{t} \cdot \mathrm{ha}^{-1}\left(\mathrm{MC}_{3}\right)$ to $50.3 \mathrm{t} \cdot \mathrm{ha}^{-1}(\mathrm{SM})$ and $20.2 \mathrm{t} \cdot \mathrm{ha}^{-1}$ $\left(\mathrm{MC}_{3}\right)$ to $18.3 \mathrm{t} \cdot \mathrm{ha}^{-1}(\mathrm{SM})$ in control of the variant. The yield of forage and dry matter ranged from 75.5 $\mathrm{t} \cdot \mathrm{ha}^{-1}\left(\mathrm{MC}_{3}\right)$ to $58.7 \mathrm{t} \cdot \mathrm{ha}^{-1}(\mathrm{SM})$ and $23.8 \mathrm{t} \cdot \mathrm{ha}^{-1}\left(\mathrm{MC}_{3}\right)$ to $20.7 \mathrm{t} \mathrm{ha}^{-1}$ (SM) in fertilization with clinoptilolite. The diferences in the yield of forage and dry matter in fertilization with clinoptilolite were better than in control of the variant, and are statistically significant $(p<0.05)$. The use of concentrated or natural zeolite with urea increased silage corn dry matter production and provided the best use of nitrogen at the higher doses of fertilizer [22]. According to the results, when cowpea seed number and fertilization with clinoptilolite increased in intercrop, forage and dry matter yields on parcels increased. Cowpea can be intercropped with maize [8] and sorghum [23] for a higher yield and quality compared with sole cropping. Legume contribution to maize in mixtures was significant and increased the total biomass yield of mixtures $[24,25]$. One of the main reasons of intercropping maize and cowpea is the increase of crude protein level in silage.

Since crude proteins are very important in cattle fodder, silage containing more crude proteins is desirable. In this study, it was found that the value of crude proteins of intercropped fodder $\mathrm{MC}_{1}, \mathrm{MC}_{2}$ and $\mathrm{MC}_{3}$ was statistically significantly $(p<0.05)$ higher than SM during a two treatments of fertilization (Table 3). According to the results, when cowpea seeds number and fertilization with clinoptilolite increased in intercrops, the content of crude protein in the mixture increased. Cowpea fodder is a rich source of crude protein, giving up to $184 \mathrm{~g} \cdot \mathrm{kg}^{-1}$ [26]. Furthermore, protein content of cowpea forage (220 $\left.\mathrm{g} \cdot \mathrm{kg}^{-1}\right)$ was higher compared to some legumes such as lablab (Lablab purpureus L.), mucuna (Mucuna pruriens L.) and grass species (Sorghum sudanense (Piper) Stapf), though it was the species least consumed by goats [27]. Maximum crude protein percentage of forage was obtained at the milky stage and minimum crude protein was achieved at the dough stage of maize growth in maize-cowpea intercropping [8].

Results in the present study were in agreement with other studies where legumes also increased crude protein concentration when in a mixture with maize $[25,28]$. This could be due to higher nitrogen availability for maize in intercropping compared with the monoculture crop [14]. In this study, it was found that the yield of crude proteins of intercropped fodder $\mathrm{MC}_{1}, \mathrm{MC}_{2}$ and $\mathrm{MC}_{3}$ was statistically significantly $(p<$ 0.05) higher than SM during a two fertilization treatments (Table 3). Treatment of $\mathrm{MC}_{3}$ had the highest yield of crude protein $2.08 \mathrm{t} \cdot \mathrm{ha}^{-1}$ in control of the variant and $2.78 \mathrm{t} \cdot \mathrm{ha}^{-1}$ in variant fertilization with 
Table 2 Fresh forage yield and dry matter yield of maize and maize-cowpea intercropped.

\begin{tabular}{lllllll}
\hline \multirow{2}{*}{ Treatments } & \multicolumn{3}{c}{ Fresh forage yield $\mathrm{t} \cdot \mathrm{ha}^{-1}$} & \multicolumn{2}{c}{${\text { Dry matter yield } \mathrm{t} \cdot \mathrm{ha}^{-1}}^{-1}$} \\
\cline { 2 - 7 } & Control & Clinoptilolite & Mean & Control & Clinoptilolite & Mean \\
\hline $\mathrm{SM}$ & $50.3 \mathrm{~b}$ & $58.7 \mathrm{c}$ & $54.5 \mathrm{~d}$ & $18.3 \mathrm{a}$ & $20.7 \mathrm{~b}$ & $19.5 \mathrm{a}$ \\
$\mathrm{MC}_{1}$ & $53.8 \mathrm{~b}$ & $65.5 \mathrm{~b}$ & $59.7 \mathrm{c}$ & $18.6 \mathrm{a}$ & $22.0 \mathrm{ab}$ & $20.3 \mathrm{a}$ \\
$\mathrm{MC}_{2}$ & $57.1 \mathrm{ab}$ & $70.8 \mathrm{ab}$ & $64.0 \mathrm{~b}$ & $19.3 \mathrm{a}$ & $23.2 \mathrm{a}$ & $21.3 \mathrm{a}$ \\
$\mathrm{MC}_{3}$ & $61.8 \mathrm{a}$ & $75.5 \mathrm{a}$ & $68.7 \mathrm{a}$ & $20.2 \mathrm{a}$ & $23.8 \mathrm{a}$ & $22.0 \mathrm{a}$ \\
Mean & $55.8 \mathrm{~b}$ & $67.6 \mathrm{a}$ & & $19.1 \mathrm{~b}$ & $22.4 \mathrm{a}$ & \\
\hline
\end{tabular}

Different letters in the column mean significant difference $(p<0.05)$.

Table 3 Content and yield of crude protein of maize and maize-cowpea intercropped.

\begin{tabular}{lllllll}
\hline \multirow{2}{*}{ Treatments } & \multicolumn{3}{c}{ Content of crude protein in $\mathrm{g} \cdot \mathrm{kg}^{-1} \mathrm{DM}$} & \multicolumn{3}{c}{ Crude protein yield in tha $^{-1}$} \\
\cline { 2 - 7 } & Control & Clinoptilolite & Mean & Control & Clinoptilolite & Mean \\
\hline $\mathrm{SM}$ & $76 \mathrm{~d}$ & $84 \mathrm{~d}$ & $80 \mathrm{~d}$ & $1.39 \mathrm{c}$ & $1.74 \mathrm{~d}$ & $1.57 \mathrm{c}$ \\
$\mathrm{MC}_{1}$ & $91 \mathrm{c}$ & $101 \mathrm{c}$ & $96 \mathrm{c}$ & $1.69 \mathrm{~b}$ & $2.22 \mathrm{c}$ & $1.96 \mathrm{bc}$ \\
$\mathrm{MC}_{2}$ & $96 \mathrm{~b}$ & $108 \mathrm{~b}$ & $102 \mathrm{~b}$ & $1.85 \mathrm{ab}$ & $2.51 \mathrm{~b}$ & $2.18 \mathrm{ab}$ \\
$\mathrm{MC}_{3}$ & $103 \mathrm{a}$ & $117 \mathrm{a}$ & $110 \mathrm{a}$ & $2.08 \mathrm{a}$ & $2.78 \mathrm{a}$ & $2.43 \mathrm{a}$ \\
Mean & $92 \mathrm{~b}$ & $103 \mathrm{a}$ & & $1.75 \mathrm{~b}$ & $2.31 \mathrm{a}$ & \\
\hline
\end{tabular}

Different letters in the column mean significant difference $(p<0.05)$.

clinoptilolite from other fodder mixtures (Table 3). From this point of view fodder produced in maize-cowpea intercrops is important not only to profit from the increase in the content of crude protein, but also from the reduction of the content of neutral detergent fibers. For this reason, the best option in maize-cowpea intercropping is the use of cowpea genotypes that provide forage with the greatest amount of pods at harvest. In addition, the level of neutral detergent fibers is associated with the stage of maturity of the fodder due to the level of the cell wall components, mainly cellulose, hemicellulose and lignin [29]. The value of a neutral detergent fiber refers to the total cell wall and consists of an acid detecting fiber fraction plus hemicellulose. In this study, it was found that the values of neutral detergent fibers of intercropped $\mathrm{MC}_{2}$ and $\mathrm{MC}_{3}$ were statistically significantly $(p<0.05)$ lower than SM during two fertilization treatments (Table 4). According to the results, when cowpea seed number and fertilization with clinoptilolite increased in intercrop, the values of neutral detergent fibers in the mixture decrase. Neutral detergent fiber is the measure of the total content of fiber (hemicellulose, cellulose and lignin) in silage.
The content of neutral detergent fiber is important in ration formulation because it reflects the amount of animal forage that animals can consume [10]. In general, the concentration of neutral detergent fibers is higher for grass than for legumes [8].

Since smaller amounts of fiber components are used for better digestion, the cowpea intercropped plots to be superior to monocrop maize in terms of neutral detergent fiber. Results in the present study were in agreement with other studies where clinoptilolite decreased NDF values in silage of maize [22]. In this paper, the value of sugar of intercropped forage $\mathrm{MC}_{1}$, $\mathrm{MC}_{2}$ and $\mathrm{MC}_{3}$ was statistically significantly $(p<0.05)$ lower than SM during a two fertilization treatments (Table 4). According to the results, when the cowpea seed number and fertilization with clinoptilolite increased in intercrop, the values of water-soluble sugar in the mixture decrase. In this paper, the value of phosphorus and calcium of intercropped forage $\mathrm{MC}_{1}, \mathrm{MC}_{2}$ and $\mathrm{MC}_{3}$ was statistically significantly $(p<$ 0.05) higher than SM during two fertilization treatments (Table 5). According to the results, when the cowpea seed number and fertilization with clinoptilolite increased in intercrop, the values of 
Table 4 Content of neutral detergent fiber and water-soluble sugars of maize and maize-cowpea intercropped.

\begin{tabular}{lllllll}
\hline \multirow{2}{*}{ Treatments } & \multicolumn{2}{l}{ Content of neutral detergent fiber in $\mathrm{g}^{\mathrm{kg}} \mathrm{g}^{-1} \mathrm{DM}$} & \multicolumn{3}{l}{ Content of water-soluble sugars in $\mathrm{g} \cdot \mathrm{kg}^{-1} \mathrm{DM}$} \\
\cline { 2 - 7 } & Control & Clinoptilolite & Mean & Control & Clinoptilolite & Mean \\
\hline $\mathrm{SM}$ & $379 \mathrm{a}$ & $327 \mathrm{a}$ & $353 \mathrm{a}$ & $148 \mathrm{a}$ & $130 \mathrm{a}$ & $139 \mathrm{a}$ \\
$\mathrm{MC}_{1}$ & $368 \mathrm{ab}$ & $318 \mathrm{ab}$ & $343 \mathrm{ab}$ & $128 \mathrm{~b}$ & $112 \mathrm{~b}$ & $120 \mathrm{~b}$ \\
$\mathrm{MC}_{2}$ & $354 \mathrm{bc}$ & $308 \mathrm{bc}$ & $331 \mathrm{bc}$ & $120 \mathrm{bc}$ & $104 \mathrm{bc}$ & $112 \mathrm{bc}$ \\
$\mathrm{MC}_{3}$ & $340 \mathrm{c}$ & $296 \mathrm{c}$ & $318 \mathrm{c}$ & $112 \mathrm{c}$ & $98 \mathrm{c}$ & $105 \mathrm{c}$ \\
Mean & $360 \mathrm{a}$ & $312 \mathrm{~b}$ & & $127 \mathrm{a}$ & $111 \mathrm{~b}$ & \\
\hline
\end{tabular}

Different letters in the column mean significant difference $(p<0.05)$.

Table 5 Content of phosphorus and calcium of maize and maize-cowpea intercropped.

\begin{tabular}{lllllll}
\hline \multirow{2}{*}{ Treatments } & \multicolumn{3}{l}{ Content of phosphorus in $\mathrm{g}^{\mathrm{kg}} \mathrm{kg}^{-1} \mathrm{DM}$} & \multicolumn{3}{l}{ Content of calcium in $\mathrm{g} \cdot \mathrm{kg}^{-1} \mathrm{DM}$} \\
\cline { 2 - 7 } & Control & Clinoptilolite & Mean & Control & Clinoptilolite & Mean \\
\hline $\mathrm{SM}$ & $2.3 \mathrm{c}$ & $2.5 \mathrm{~d}$ & $2.4 \mathrm{~d}$ & $3.5 \mathrm{~d}$ & $3.3 \mathrm{~d}$ & $3.4 \mathrm{~d}$ \\
$\mathrm{MC}_{1}$ & $2.4 \mathrm{bc}$ & $2.6 \mathrm{c}$ & $2.5 \mathrm{c}$ & $3.9 \mathrm{c}$ & $3.7 \mathrm{c}$ & $3.8 \mathrm{c}$ \\
$\mathrm{MC}_{2}$ & $2.5 \mathrm{ab}$ & $2.7 \mathrm{~b}$ & $2.6 \mathrm{~b}$ & $4.3 \mathrm{~b}$ & $4.1 \mathrm{~b}$ & $4.2 \mathrm{~b}$ \\
$\mathrm{MC}_{3}$ & $2.6 \mathrm{a}$ & $2.8 \mathrm{a}$ & $2.7 \mathrm{a}$ & $4.7 \mathrm{a}$ & $4.5 \mathrm{a}$ & $4.6 \mathrm{a}$ \\
Mean & $2.45 \mathrm{~b}$ & $2.65 \mathrm{a}$ & & $4.10 \mathrm{a}$ & $3.90 \mathrm{~b}$ & \\
\hline
\end{tabular}

Different letters in the column mean significant difference $(p<0.05)$.

phosphorus and calcium in the mixture indecrase. Contribution of legumes with sweet sorghum in mixtures significantly increased potassium, phosphorus, calcium and magnesium in fresh fodder [30, 31].

\section{Conclusion}

The conclusion of the present study is that intercropping of maize with cowpea at various planting densities and fertilization with natural zeolite clinoptilolite was shown to be an effective way to influence fresh biomass production, dry matter and crude protein yield to enhance nutrient quality of forage. Intercropping of maize with cowpea and fertilization with natural zeolite clinoptilolite increased values of crude protein, phosphorus and calcium and decreased values of neutral detergent fibre and water-soluble sugar concentrations in forage. Finally, intercropping with 75,000 plants $^{-1} \mathrm{o}^{-1}$ of maize and 75,000 plants ha ${ }^{-1}$ of cowpea and fertilization with natural zeolite clinoptilolite was most suitable according to the nutrient composition in forage.

\section{Acknowledgements}

Authors gratefully acknowledge the financial support from Mineral Promet d.o.o., Croatia and donation of natural zeolite clinoptilolite for this research.

\section{References}

[1] Anil, L., Park, J., and Phipps, R. H. 2000. "The Potential of Forage-Maize Intercrops in Ruminant Nutrition." Animal Feed Science and Technology 85: 157-64.

[2] Stoltz, E., Nadeau, E., and Wallenhammar, A. C. 2013. "Intercropping Maize and Fababean for Silage under Swedish Climate Conditions." Agricultural Research 2 (1): 90-7.

[3] Kipkemoi, P. L., Wasike, V. W., Ooro, P. A., Riungu, T. C., Bor, P. K., and Rogocho, L. 2010. "Effects of Intercropping Pattern on Soybean and Corn Yield in Central Rift Valley of Kenya." 1478-84.

[4] Costa, P. M., Villela, S. D. J., Leonel, F. D. P., Araújo, K. G., Ruas, J. R. M., Coelho, F. S., et al. 2012. "Intercropping of Corn, Brachiaria Grass and Leguminous Plants: Productivity, Quality and Composition of Silages." Revista Brasileira de Zootecnia 41: 2144-9.

[5] Contreras-Govea, F. E., Muck, R. E., Armstrong, K. L., and Albrecht, K. A. 2009. "Nutritive Value of Corn Silage in Mixture with Climbing Beans." Animal Feed Science and Technology 150: 1-8. DOI: https://doi.org/10.1016/j.anifeedsci.2008.07.001.

[6] Zhu, Y., Bai, C. S., Guo, X. S., Xue, Y. L., and Ataku, K. 2011. "Nutritive Value of Corn Silage in Mixture with Vine Peas." Animal Production Science 51: 1117-22. 
DOI: https://doi.org/10.1071/AN11125.

[7] Javamard, M. N., Javanshir, A., Moghaddam, M., and Janmohammadi, H. 2009. "Forage Yield and Quality in Intercropping of Maize with Different Legumes as Double-Cropped." Journal of Food Agriculture and Environment 7: 163-6.

[8] Dahmardeh, M. A., Ghanbari, B., Syasar, B., and Ramroudi M. 2009. "Effect of Intercropping Maize (Zea mays L.) with Cowpea (Vigna unguiculata L.) on Green Forage Yield and Quality Evaluation." Asian Journal of Plant Science 83: 235-9. DOI: https://doi.org/10.3923/ajps.2009.235.239.

[9] Dhima, K., Lithourgidis, A., Vasilakoglou, I., and Dordas, C. 2007. "Competition Indices of Common Vetch and Cereal Intercrops in Two Seeding Ratio." Field Crops Research 100: 249-56. DOI: https://doi.org/10.1016/j.fcr.2006.07.008.

[10] Lithourgidis, A. S., Vasilakoglou, I. B., Dhima, K. V., Dordas, C. A., and Yiakoulaki, M. D. 2006. "Forage Yield and Quality of Common Vetch Mixtures with Oat and Triticale in Two Seeding Ratios." Field Crops Research 99 (2): 106-13.

[11] Anil, A., Park, P., Phipps, P., and Miller, M. 1998. "Temperate Intercropping of Cereals for Forage: A Review of the Potential for Growth and Utilization with Particular Reference to the UK." Grass Forage Science 53: 301-17.

[12] Banik, P., Midya, A., Sarkar, B. K., and Ghose, S. S. 2006. "Wheat and Chickpea Intercropping Systems in an Additive Series Experiment: Advantages and Weed Smothering." European Journal of Agronomy 24: 325-32.

[13] Vasilakoglou, I., Dhima, K., Lithourgidis, A., and Eleftherohorinos, I. 2008. "Competitive Ability of Winter Cereal-Common Vetch Intercrops against Sterile Oat." Experimental Agriculture 44: 509-20.

[14] Eskandari, H., Ghanbari, A., Galavi M., and Salari, M. 2009. "Forage Quality of Cowpea (Vigna sinensis) Intercropped with Corn (Zea mays) as Affected by Nutrient Uptake and Light Interception." Notulae Botanicae Horti Agrobotanici Cluj-Napoca 37: 171-4.

[15] Putnam, D. H., Herbert, S., and Vargas, J. 1985. "Intercropping Maize-Soybean Studies, Yield Composition and Protein." Journal of Experimental Agriculture 22: 375-81.

[16] Ramesh, K., Biswas, A. K., Somasundaram, J., Subba, and Rao, A. 2010. "Nanoporous Zeolites in Farming: Current Status and Issues Ahead." Current Science 99 (6): 760-5.

[17] Butorac, A., Filipan, T., Basic, F., Butorac, J., Mesic, M., and Kisic, I. 2002. "Crop Response to the Application of Special Natural Amendments Based on Zeolite Tuff." Rostlinná Výroba 48: 118-24.
[18] AOAC (Association of Official Analytical Chemists). 2000. Official Methods of Analysis of AOAC International (17th ed.). Washington DC.

[19] Van Soest, P. J., Robertson, J. B., and Lewis, B. A. 1991. "Methods for Dietary Fiber, Neutral Detergent Fiber, and Nonstarch Polysaccharides in Relation to Animal Nutrition.” Journal of Dairy Science 74: 3583-97.

[20] Tomas, T. A. 1977. "An Automated Procedure for the Determination of Soluble Carbohydrate in Herbage." Journal of Science of Food and Agriculture 28: 639-42.

[21] Statistical Analysis System SAS. 2002: User's Guide: Statistics, Version 8.02. SAS Institute Inc. Cary, USA.

[22] Bernardi, A. C. C., Souza, G. B., Polidoro, J. C., Monte, M. B. M., and Paiva, P. R. P. 2011. "Yield, Quality Components, and Nitrogen Levels of Silage Corn Fertilized with Urea and Zeolite." Communications in Soil Science and Plant Analysis 42: 1266-75.

[23] Azraf Ul Haq, A., Riaz, A., Naeem, M., and Tanveer, A. 2007. "Performance of Forage Sorghum Intercropped with Forage Legumes under Different Planting Patterns." Pakistan Journal of Botany 39 (2): 431-9.

[24] Geren, H., Avcioglu, R., Soya, H., and Kir, B. 2008. "Intercropping of Corn with Cowpea and Bean Biomass Yield and Silage Quality." African Journal of Biotechnology 22: 4100-4.

[25] Htet, M. N., Soomro, N. S., and Jiang Bo H. 2016. "Effect of Intercropping of Maize (Zea mays L.) and Soybean (Glycine max L.) on Green Forage Yield and Quality Evaluation.” IOSR Journal of Agriculture and Veterinary Science 9 (12): 59-63.

[26] Khan, A., Bari, A., Khan, S., Hussain, N. S., and Zada, I. 2010. "Performance of Cowpea Genotypes at Higher Altitude of NWFP." Pakistan Journal of Botany 42: 2291.

[27] Gwanzura, T., Ngambi, J. W., and Norris, D. 2011. "Effects of Selected Legumes Species and Forage Sorghum Hay Grown in Limpopo Province on Voluntary Intake and Relative Platability Indices of Pedi Goats." Asian Journal of Animal and Veterinary Advances 6 (12): 1249-55.

[28] Dawo, M. I., Wilkinson, J. M., Sanders, F. E., and Pilbeam, D. J. 2007. "The Yield and Quality of Fresh and Ensiled Plant Material from Intercropped Maize (Zea mays L.) and Beans (Phaseolus vulgaris)." Journal Science of Food and Agriculture 87 (7): 1391-9.

[29] Mugweni, B. Z., Titterton, M., Maasdorp, B. V., and Gandiya, A. F. 2000. "Effect of Mixed Cereal Legume Silages on Milk Production from Lactating Holstein Dairy cows (R7010)." 3rd Workshop Livest. Prod. Prog. Projects, Matobo, Zimbabwe, 82-9.

[30] Terzić, D., Stošić, M., Dinić, B., Lazarević, D., Radović, 
Influence of Intercropping Maize with Cowpea and Fertilization with Clinoptilolite on

Forage Yield and Quality

J. 2004. "Productivity of Sorghum and Soybean as Mixed Crops in after Crop Seeding." Biotechnology in Animal Husbandry 20 (3-4): 169-77.

[31] Basaran, U., Copur, Dogrusoz, M., Gulumser, E., and
Mut, H. 2017. "Hay Yield and Quality of Intercropped Sorghum-Sudan Grass Hybrid and Legumes with Different Seed Ratio." Turkish Journal of Field Crops 22 (1): 47-53. 